\title{
Plant Growth Regulators Modify Fruit Set, Fruit Quality, and Return Bloom in Sweet Cherry
}

\author{
Irfan Ali Sabir, Xunju Liu, and Songtao Jiu \\ Department of Plant Science, School of Agriculture and Biology, Shanghai Jiao \\ Tong University, Minhang, Shanghai 200240, People's Republic of China
}

\begin{abstract}
Matthew Whiting
Department of Horticulture and Landscape Architecture, Washington State University, Irrigated Agriculture Research and Extension Center, $24106 \mathrm{~N}$. Bunn Road, Prosser, WA 99350
\end{abstract}

\section{Caixi Zhang}

Department of Plant Science School of Agriculture and Biology, Shanghai Jiao Tong University, Minhang, Shanghai 200240, People's Republic of China

Additional index words. auxin, crop load, cytokinin, gibberellin, PGR, polyamine, Prunus avium

\begin{abstract}
Sweet cherry (Prunus avium L.) is a valuable fruit crop worldwide. Farmers' incomes are closely related to fruit quantity and quality, yet these can be highly variable across years. As part of a broader project for optimizing fruit set and fruit quality in sweet cherries, this study was conducted to evaluate the potential of various plant growth regulators (PGRs) for improving fruit set and fruit quality. Cytokinins, gibberellins, auxin, and polyamines were used as treatments. Treatments were applied as foliar sprays at full bloom to 'Bing' and three low-productivity genotypes, 'Regina', 'Tieton', and 'PC8011-3'. We assessed the fruit set, fruit quality, and return bloom from each treatment. 4-chlorophenoxyacetic acid (4-CPA) increased fruit set by $53 \%$ and $36 \%$ in 'Bing' and 'Tieton', respectively. The combination of gibberellin $(\mathbf{G A})_{3}+\mathbf{G A}_{4 / 7}$ was more effective for improving fruit set than other isomers of gibberellin alone. Cytokinin treatments had slight adverse effects or no effect on fruit set except for CPPU. In 'PC8011-3', both N-(2-chloro-4-pyridyl)-N'-phenylurea (CPPU) and 4-CPA enhanced fruit set by $\approx 81 \%$ and $100 \%$ compared with untreated control. The response of cherry trees to polyamine sprays depended on the properties of the cultivars and the treatment concentration. Foliar application of $\mathbf{G A}_{3}, \mathbf{G A}_{4 / 7}$, or N-phenyl-N'-(1, 2, 3-thiadiazol-5-yl) urea (TDZ) in 'Bing' trees has negative effects on return bloom, whereas $\mathrm{GA}_{1}$ can increase the yield and flower buds. These results suggest that PGRs may have varied effects on sweet cherry fruit set and that more work is needed to develop practical programs for improving yield security.
\end{abstract}

Sweet cherry (Prunus avium L.) is an economically important temperate tree fruit species of the Rosaceae family. In the past 20 years, the global production of sweet cherries has rapidly increased due to the reported health benefits from consumption and the high potential profits for producers (QueroGarcia et al., 2014). The cherry fruit is a nutrient-dense food that contains large quantities of essential nutrients and bioactive food components such as vitamin C, polyphenols, carotenoids, potassium and fiber, while being comparatively low in calories (McCune et al., 2010). Cherries are also high in tryptophan,

Received for publication 18 Mar. 2021. Accepted for publication 19 May 2021.

Published online 16 July 2021.

C.Z. and M.W. are the corresponding authors. E-mail: acaizh@sjtu.edu.cn or mdwhiting@ wsu.edu.

This is an open access article distributed under the CC BY-NC-ND license (https://creativecommons. org/licenses/by-nc-nd/4.0/). serotonin, and melatonin (Cubero et al., 2010; Garrido et al., 2012). In determining crop value, sweet cherry yield and fruit size are the key attributes. In many producing regions around the world, average yields can exceed $20 \mathrm{t} / \mathrm{ha}$; however, there is a negative correlation between crop load per tree and fruit quality (Whiting and Lang, 2004). Moreover, the sweet cherry yield is highly variable among cultivars, years, and production regions. Low fruit set rate or premature fruitlet abscission are both factors that contribute to lower production (i.e., fruit drop). Multiple factors contribute toward suboptimal fruit set, including inadequate insect pollination, low pollen germination, low viable pollen, low pollen tube growth, rapid ovule senescence, lack of bloom overlap with pollenizers, or insufficient pollenizer density. Planting several pollenizer genotypes and raising the density of pollenizer trees are two cultural practices that growers may use to address problems with pollenizers and low fruit sets. Applying PGRs to extend the successful pollination period is an additional or complementary solution to enhance fruit set. Treatments with PGRs can elicit a wide variety of effects and plant responses, including manipulation of fruit size, fruit set, fruit maturation, and fruit shape in tree fruit species, including sweet cherries (Greene, 1988; Ryugo, 1988; Stösser and Anvari, 1982). Various concentrations of PGRs have different effects on fruit set in pear (Pyrus communis) (Zhang et al., 2007), plum (Prunus domestica) (Webster, 1984), and sweet cherries (Zhang and Whiting, 2011).

There are myriad studies on the effects of PGRs in tree fruit, and results vary with PGR application timing, concentration, and even with application technology. In previous studies, preharvest applications of gibberellins during the stage II-III transition in sweet cherry have increased fruit size and delayed maturation (Clayton et al., 2006; Facteau et al., 1985; Kappel and MacDonald, 2002, 2007; Lenahan et al., 2006; Proebsting et al., 1973; Stern et al., 2007; Usenik et al., 2005; Zhang and Whiting, 2011, 2013). Similarly, different auxins have been applied to improve fruit size in Prunus species, including plums, cherries, and apricots ( $P$. armeniaca). Gibberellins also play a vital role in pollen germination (Zhang et al., 2010), fruit set and fruit development in pear (Zhang et al., 2007) and sweet cherry (Zhang and Whiting et al., 2011, 2013), and uniconazole, an inhibitor of gibberellins biosynthesis, is an effective blossom thinner for 'Bing' cherry (Stern et al., 2007). Before stage II of fruit growth in sweet cherry, treatments with indole acetic acid and GA have beneficial effects on fruit growth (Kondo et al., 1998; Shiozaki et al., 1997). The close relationship between $\mathrm{GA}_{3}$ and abscisic acid illustrated fruit development after pit hardening in sweet cherry.

The fruit set rate is controlled by several key factors, including endogenous and exogenous PGRs. Fertilization and the subsequent metabolic processes have a significant bearing on fruit quality. Cell division appears to occur for only a $\approx 12$ - to 14 -d period following fertilization (Olmstead et al., 2008), and this stage is therefore targeted for improving quality with exogenous PGRs. The applications of gibberellic acid, auxin, and cytokinins are responsible for growth at a certain level, but their synergistic effect is applicable for developing a normal fruit (Carrera et al., 2012). $\mathrm{GA}_{3}$ increases the fruit size, improve fruit firmness and delay the maturity of sweet cherries. Interestingly, foliar applications of prohexadione-calcium and GAs on fruit development stage II influence the canopy source-sink relations and improve fruit quality along with shelf life of 'Bing' (Zhang and Whiting, 2011).

The sweet cherry fruit set is a perennial concern in commercial practice due to the pollinizer + pollinator model and sensitivity to weather. Exogenous application of PGRs represents an alternative strategy to stabilize fruit set by extending the effective pollination period and potentially improving fruit quality. In the following, we report on research conducted over 2 years, evaluating the potential 


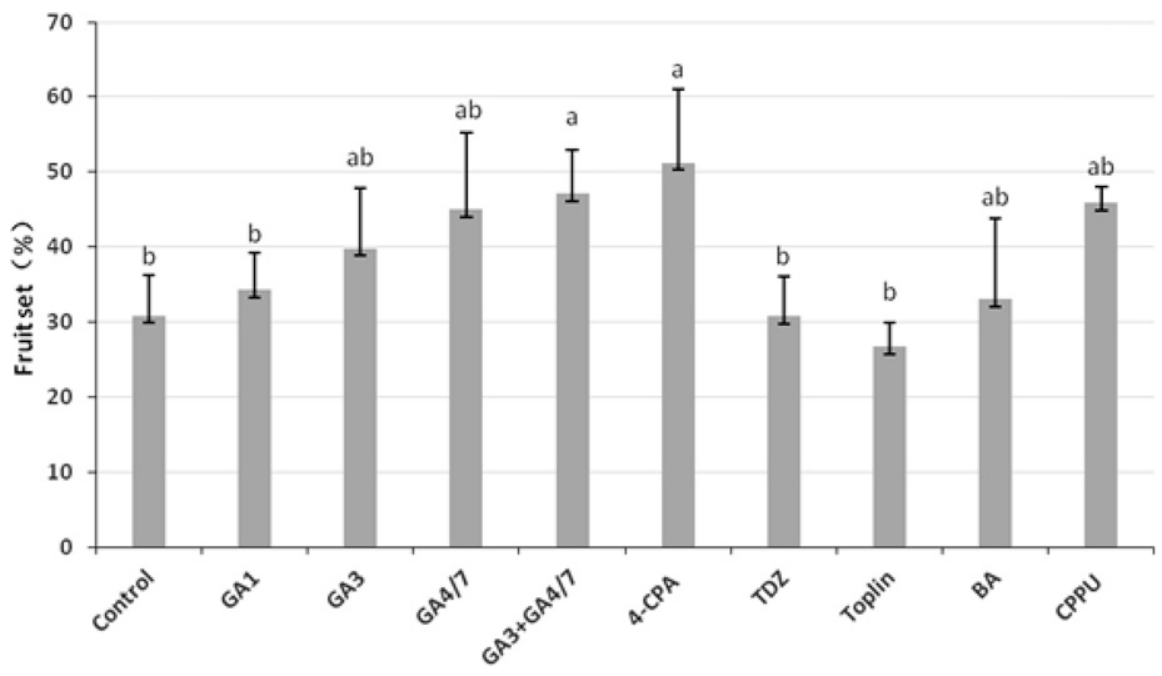

Fig. 1. Influence of plant growth regulators (PGRs) applied at full bloom on fruit set in sweet cherry 'Bing'. Data are average \pm SE. Different letters represent a significant difference among PGRs at a $P$ level of 0.05 (least significant difference test). 4-CPA $=4$-chlorophenoxyacetic acid; $\mathrm{BA}=\mathrm{N6}$ benzyladenine; CPPU = N-(2-chloro-4-pyridyl)-N'-phenylurea; GA = gibberellin; TDZ $=\mathrm{N}$-phenylN'-(1, 2, 3-thiadiazol-5-yl) urea; Topolin = 6-(3-hydroxybenzylamino) purine.

of foliar application of PGRs to manipulate fruit set of sweet cherries.

\section{Materials and Methods}

This research was conducted at Washington State University's (WSU) Roza farm, north of Prosser, WA, (lat. $46.2^{\circ} \mathrm{N}$, long. $119.7^{\circ} \mathrm{W}$ ). All 10-year-old sweet cherry trees-'Bing', 'Tieton', 'Regina', and 'PC 8011-3'-were trained to central leader architecture. Ten-yearold trees were used for this experiment. All trees were treated with similar pattern of irrigation and fertigation.

'Bing' is the most widely planted cultivar of sweet cherries in the Pacific Northwest of the United States, whereas 'Tieton', 'PC80113', and 'Regina' are newer genotypes with low fruit set. 'Regina' is a late-season cultivar ('Bing' $+10 \mathrm{~d}$ ), 'Tieton' fruit ripens $\approx 1$ week before 'Bing', and 'PC8011-3', an advanced selection from the breeding program at WSU, is a yellow-fleshed blush genotype that ripens a few days before 'Bing'.

\section{Chemicals}

Four classes of PGRs were tested, including auxins, gibberellins, cytokinins, and polyamines. These were used to analyze their effect on fruit set (i.e., fertilization rate) and fruit growth. Our work included synthetic cytokinins: CPPU, N6-benzyladenine (BA), TDZ, and 6-(3-hydroxybenzylamino) purine (metaTopolin); gibberellin isomers include $\mathrm{GA}_{1}$, $\mathrm{GA}_{3}$, and the mixture of $\mathrm{GA}_{4}$ and $\mathrm{GA}_{7}\left(\mathrm{GA}_{4}\right.$ 7); a synthetic auxin, 4-CPA; and three polyamines, including diamine putrescine (Put), triamine spermidine (Spd), and tetraamine spermine (Spm). PGRs were purchased from OlChemIm Ltd. (Olomouc, Czech Republic).

\section{PGR application}

The experiment included 14 treatments, including a 'control' of limbs treated with full bloom. Six replicate limbs with uniform Six replicate limbs with water alone. All treatments were applied using hand-gun sprayers at full bloom stage on four 'Regina', and 'PC 8011-3', PGing', Tieton', at different concentrations: 25 ppm for gibberellins, $15 \mathrm{ppm}$ for cytokinins, $30 \mathrm{ppm}$ for auxin, and $50 \mathrm{ppm}$ for polyamines in the first year (2009), whereas 100 and 200 ppm were vigor on three cherry trees for each cultivar grafted on 'Gisela 6' were selected for PGRs treatment. For full bloom spray and fruit set calculation, the dead and unopened flowers on selected limbs were removed, and the total flowers remaining were counted. The fruit set was determined by counting fruit at harvest and calculated as a percent of available, viable flowers. Fifty fruits were evaluated for fruit size measurement with fruit length and fruit width until harvest with 7-d intervals. Also, to investigate the wind effects on pollination and fruit set of sweet cherries, both 'PC 8011-3' trees on the roadside and interior were selected as the controls for PGRs treatment.

\section{Pollen tube growth and ovule viability}

To examine the effects of foliar application of PGRs on effective pollination period, treated flowers after spray were sampled and fixed in formaldehyde alcohol acetic acid (FAA), 10\%:50\%:5\% + 35\% water) to analyze further the pollen tube growth and ovule viability in 'Tieton'. After the application of PGRs, including Put, Spm, Spd, $\mathrm{GA}_{3}, \mathrm{GA}_{4 / 7}$, CPPU, and 4-CPA, the flowers were sampled at 24-h intervals with open pollination until $168 \mathrm{~h}$ after spraying. FAA solution containing 95\% ethanol : glacial acetic acid : $37 \%$ formalin 10:1:2 (v/v/v) was used for pistil fixation. Distilled water was repeated three times $30 \mathrm{~min}$ to rinse flower tissues and then shifted to $5 \mathrm{~N}$ sodium hydroxide solution. Samples were subsequently transferred to a $0.1 \%$ Aniline Blue solution after 4 to $6 \mathrm{~d}$ when the tissue was softened and left until
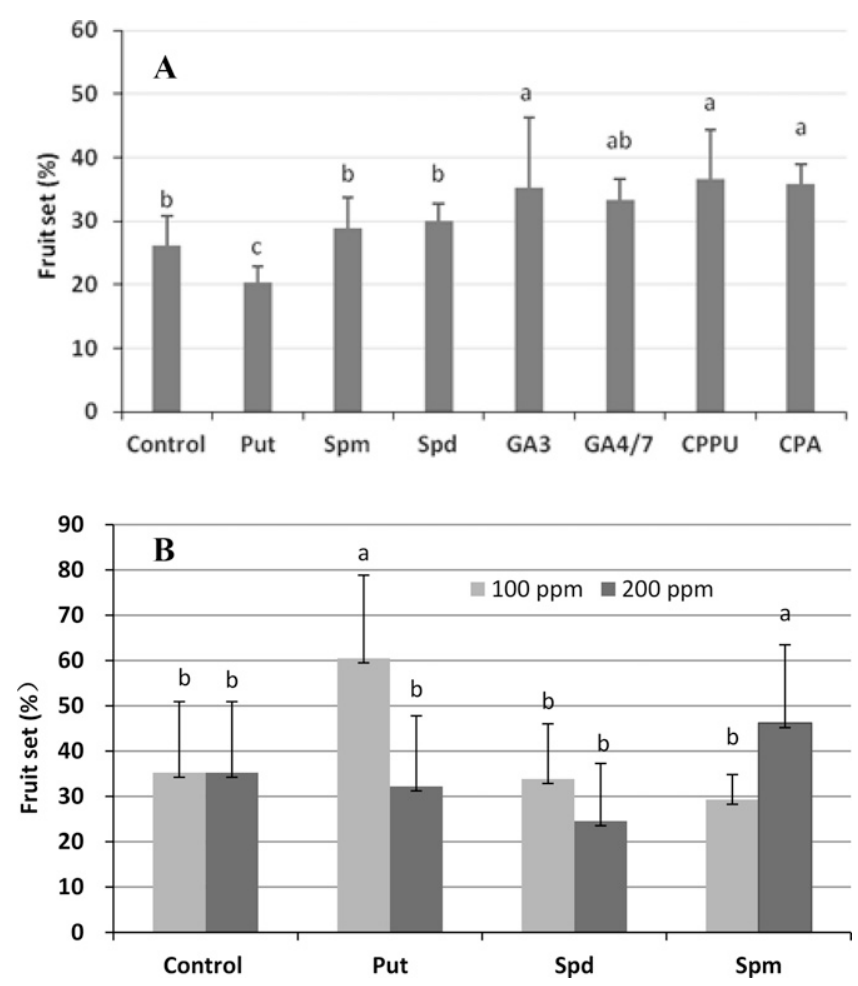

Fig. 2. Effect of plant growth regulators (PGRs) applied at full bloom on fruit set in sweet cherry 'Tieton'. Data are average $\pm \mathrm{SE}$. Different letters represent a significant difference between PGRs at a $P$ level of 0.05 (least significant difference test). $\mathrm{CPA}=4$-chlorophenoxyacetic acid; $\mathrm{CPPU}=\mathrm{N}$ (2-chloro-4-pyridyl)-N'-phenylurea; GA = gibberellin; $\mathrm{Put}=$ putrescine; $\mathrm{Spd}=$ triamine spermidine; $\mathrm{Spm}=$ tetraamine spermine. 
the pistils became transparent, $\approx 10$ to $14 \mathrm{~d}$. Whole pistils were then placed on a slide with one or two drops of $50 \%$ glycerol and then flattened with a coverslip. Slides were examined by using an Olympus BX51 fluorescence microscope equipped with a DP70 digital camera system.

\section{Fruit quality analyses}

Individual fruit was weighed for evaluating fruit weight distribution. Exocarp color was evaluated for categorization manually using the sweet cherry color plates (a 1 to 7 scale) developed by the Center Technique Interprofessional des Fruit et Legumes (France). Fruit number in each category was counted and calculated for color distribution and color rating. Subsequently, all fruits were subjected to concomitant firmness testing and equatorial diameter measurement using a calibrated FirmTech II (BioWorks, Inc., Wamego, KS). Then, 25 fruits were randomly selected for five, five-fruit replicates for the determination of soluble solid contents. A digital refractometer (Atago, Japan) was used to measure the total soluble solids, and $0.5 \mathrm{~mL}$ of juice was used for the measurement.

\section{Return bloom}

To investigate the effects of the PGRs on return bloom or the on- and off-year fruiting, the flower bud formation and flower development were investigated after PGRs application in sweet cherry 'Bing'. Two-year-old shoots treated with PGRs were selected for return bloom investigation. The number of flower buds per spur was counted before budbreak, and the number of flowers per bud was counted at the stage of first white.

\section{Statistical analyses}

A randomized complete block design was used in all research trials. While using the general linear models program of the SAS statistical analysis package (SAS Institute, Cary, NC), the data were analyzed through analysis of variance (ANOVA). Duncan's new multiple range test and least significant difference test were used to compare treatments when ANOVA showed significant differences between means.

\section{Results and Discussion}

A global concern for commercial sweet cherry producers is the significant variability in crop production from season to season and among genotypes. The aged system of pollination for self-sterile sweet cherry cultivars has been one of planting pollinizer trees and importing honeybees as pollinators. This approach is beset with variability, sensitivity to weather, and climate change. As an alternative strategy to improve yield security and consistency, we have investigated the potential for improving fruit set using PGRs. Various PGRs have been evaluated and several commercial treatments adopted, offering the potential to manipulate fruit size, fruit set, fruit maturation, and fruit shape. In a previous study, Zhang and Whiting (2011) reported on the efficacy of many PGRs applied in lanolin paste to individual fruit pedicels. In the current study, we investigated the efficacy of PGRs applied in a more commercially relevant manner with a pressurized sprayer to entire fruiting limbs.

\section{Fruit set}

'Bing'. Exogenous hormones and growth regulators are known to increase fruit set in woody plant species (Crane et al., 1961). Ten treatments, including four gibberellins $\left(\mathrm{GA}_{1}\right.$, $\mathrm{GA}_{3}, \mathrm{GA}_{4 / 7}$, and $\left.\mathrm{GA}_{3}+\mathrm{GA}_{4 / 7}\right)$, four cytokinins (BA, CPPU, Topolin, and TDZ), one auxin isomer (4-CPA) and $\mathrm{H}_{2} \mathrm{O}$ (control), were tested on sweet cherry 'Bing'. We found that several PGRs significantly affected the fruit set in 'Bing'. Evidence suggests that auxins NAA and 4-CPA showed the greatest effects on fruit set and development in pear and tomato (Greene, 1988). In our work, 4CPA increased fruit set by as much as $53 \%$ (Fig. 1) compared with the untreated 'Bing'. Gibberellin isomers also improved fruit set by $34.3 \%$ to $47.1 \%$ compared with the untreated control. Our previous evaluation justified that $\mathrm{GA}_{4}, \mathrm{GA}_{7}$, and CPPU are very effective in inducing parthenocarpic fruit growth, whereas $\mathrm{GA}_{1}, \mathrm{GA}_{3}$, and IAA have no ability to induce parthenogenesis in Japanese pear. However, single or several applications of $\mathrm{GA}_{3}$ improved fruit set compared with pollination in Vaccinium corymbosum (Cano-Medrano and Darnell, 1998), and the combination of $\mathrm{GA}_{7}$ and $\mathrm{GA}_{4}$ also improved fruit set in apple (Modlibowska, 1972). Both $\mathrm{GA}_{3}$ and $\mathrm{GA}_{4 / 7}$ rather than $\mathrm{GA}_{1}$ could slightly increase the fruit set, but the increment was not statistically significant in 'Bing'. Furthermore, the combination of $\mathrm{GA}_{3}+\mathrm{GA}_{4 / 7}$ showed better efficacy for improving fruit set compared with other isomers of gibberellin alone. $\mathrm{GA}_{3}$ alone did not statistically improve final fruit set (Fig. 1), supporting that rapid growth was observed after $\mathrm{GA}_{3}$ treatment in 'Bing' and 'Black Heart' initially but then shriveled and dropped (Misra and Sharma, 1972; Rebeiz and Crane, 1961). Consequently, it appeared that combinations of gibberellin isomers were more effective for improving the final fruit set than applied alone. Exogenous cytokinins significantly increased the fruit set in Vitis vinifera (Weaver et al., 1965). CPPU caused an increment in fruit set in seeded and seedless grapes when applied at bloom, and the effect was timing and rate dependent. However, cytokinins showed no significant difference in improving fruit set except for CPPU treatment with $\approx 15 \%$ higher than control in 'Bing' (Fig. 1).

'Tieton'. Seven treatments, including three polyamines (Put, Spd, and Spm), two gibberellins $\left(\mathrm{GA}_{3}\right.$ and $\left.\mathrm{GA}_{4 / 7}\right)$, one cytokinin (CPPU), and one auxin (4-CPA), were examined with water-sprayed control. The fruit set in control was high for 'Tieton', a cultivar that typically exhibits fruit set close to $10 \%$ (M. Whiting, unpublished data), at $\approx 25 \%$ (Fig. 2A). Treatment with CPPU, 4-CPA, $\mathrm{GA}_{3}$, and $\mathrm{GA}_{4 / 7}$ showed effectively improved fruit set up to $36.7 \%, 35.9 \%, 35.3 \%$, and $33.3 \%$, respectively, whereas polyamines did not show significant effects on the fruit set. We observed no significant difference in fruit set after polyamines (Spm and Spd) application. In contrast, treatment with $50 \mathrm{ppm}$ Put resulted in a significantly lower fruit set (Fig. 2A).

Polyamines are involved in cell division and play a role in fruit in olive, litchi, and

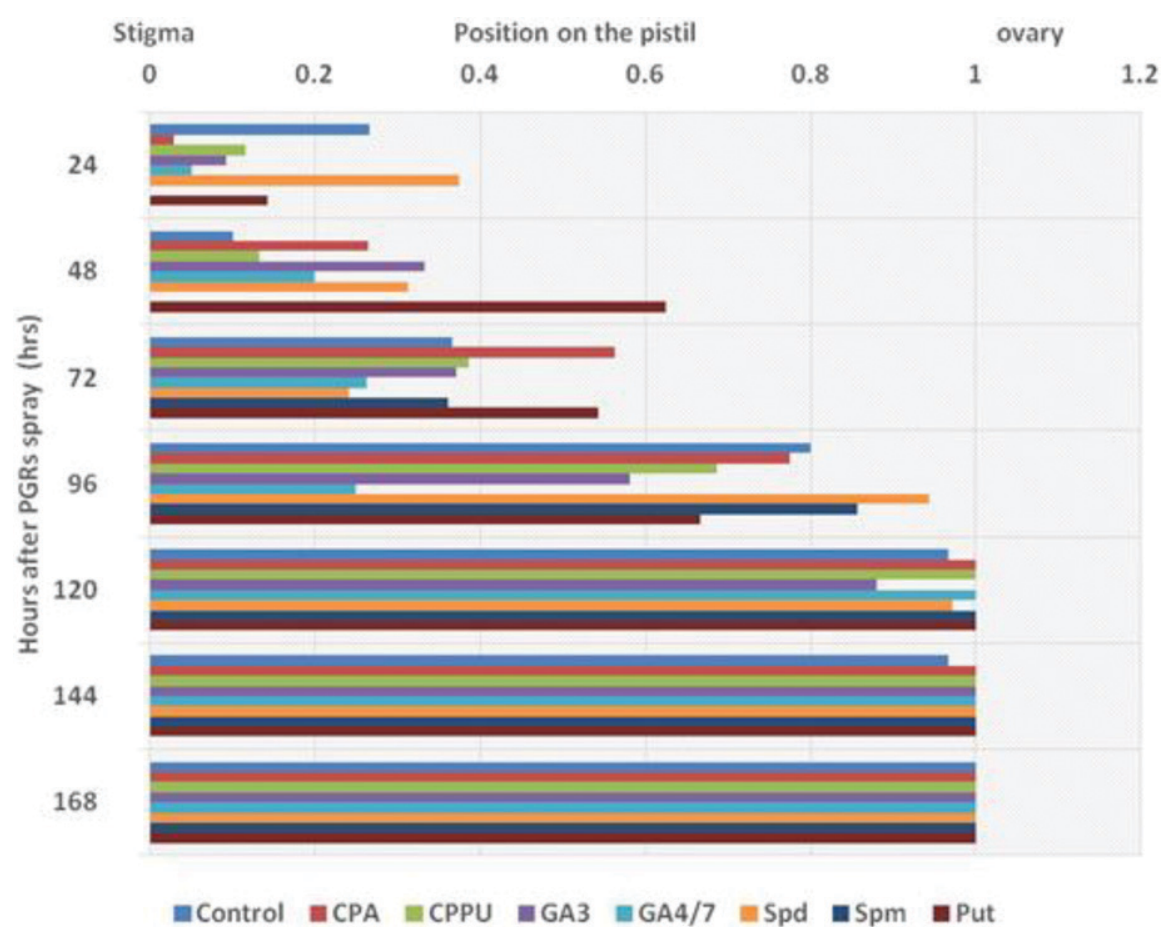

Fig. 3. Effect of foliar application of plant growth regulators at full bloom on pollen tube growth in sweet cherry 'Tieton'. $\mathrm{CPA}=4$-chlorophenoxyacetic acid; $\mathrm{CPPU}=\mathrm{N}-(2$-chloro-4-pyridyl)-N'-phenylurea; $\mathrm{GA}=$ gibberellin; $\mathrm{Put}=$ putrescine; $\mathrm{Spd}=$ triamine spermidine; $\mathrm{Spm}=$ tetraamine spermine. 
apple (Biasi et al., 1991; Mitra and Sanyal, 1990). Polyamine sprays, in one study, increased fruit set on a spur apple cultivar and the application at full bloom caused higher fruit quality maintenance than those applied before anthesis (Costa et al., 1983).

Polyamines were tested again with different concentrations. In the second year, greater concentrations of polyamines (e.g., 100 and 200 $\mathrm{ppm}$ ) were applied to investigate the response to the fruit set. Again, the control fruit set was unusually high at $\approx 35 \%$ (Fig. $2 \mathrm{~B}$ ). Putrescine treatment at $100 \mathrm{ppm}$ had the greatest effect on fruit set, increasing it to $\approx 60 \%$, increasing $\approx 73 \%$. However, the highest concentration (200 ppm) did not affect the fruit set. Spd has no significant effect on fruit set at either concentration. In contrast, Spm was ineffective at $100 \mathrm{ppm}$ but increased fruit set by $\approx 32 \%$ over the control when applied at $200 \mathrm{ppm}$. Lower concentration of Put $(50 \mathrm{ppm})$ thinned the fruit set while a higher concentration boomed the fruit set compared with Spd and Spm. The same results were also examined in sweet oranges, where Put enhanced the fruit set and gave the highest fruit yield (729.3 fruit/tree) compared with Spd, Spm, and control (Saleem et al., 2006).

'Regina'. 'Regina' is a sweet cherry cultivar that, like 'Tieton, exhibits low productivity. It is a late flowering genotype with fruit harvested about $10 \mathrm{~d}$ after the midseason standard, 'Bing'. Polyamines (Put, Spm, and Spd) were tested at 50 ppm on 'Regina' at full bloom, and only Spd improved fruit set compared with the other treatments (Fig. 5A). The fruit set overall was low, less than $4 \%$ on average. Similar to the result with 'Tieton', $50 \mathrm{ppm}$ of Put also decreased fruit set in 'Regina'. The following year, polyamines were again tested with 100 ppm and $200 \mathrm{ppm}$. The improved fruit set was observed at $100 \mathrm{ppm}$, but an adverse effect was noted when the concentration applied was 200 ppm, except in Spd. Only Spd at 200 ppm improved fruit set, for which, similar to 100 ppm, both Put and Spm at 200 ppm reduced fruit set. Specific polyamines with specific concentrations are essential for fruit set increment. Same findings were also examined in mango, where Put, Spd, Spm was used for fruit set enhancement (Singh and Singh, 1995).

'PC8011-3'. The effect of 4-CPA and CPPU on fruit set were investigated on cherry genotype 'PC8011-3' (an advanced selection from the WSU cherry breeding program that exhibits poor fruit set). In this study, two untreated applications were selected, roadside (Control R) and interior (Control I), to check the wind interception for open pollination in sweet cherries. Both CPPU and 4-CPA enhanced fruit set $\approx 81 \%$ and $100 \%$ compared with the Control I, respectively. The same fruit set increment was observed in tomatoes when treated with 4-CPA (Gemici et al., 2006) and in Japanese persimmon when CPPU was applied.

Interestingly, it was also observed that Control $\mathrm{R}$ accumulate the highest fruit set up to $\approx 550 \%$ compared with Control I and higher than the treatments with PGRs (Fig. 6). The trees investigated here on the roadside block were about $35 \mathrm{~m}$ away from the nearest block planted with sweet cherries 'Tietion', 'Lapins', 'Summit', and 'Rainer'. In general, the wind has not been considered a common factor in pollinating Prunus spp., including cherries and plums, and honeybees are by far the majority of the insect visitors to cherry blossom (Holzschuh et al., 2012). Wind pollination significantly impacts the fruit set in 'PC-8011-3' and increases the fruit set up to $400 \%$ compared with all other treatments. The same result was also confirmed in blueberry, where wind positively improved the fruit set and fruit size (Isaacs and Kirk, 2010).

\section{Effective pollination period}

The effective pollination period in plants is the difference between ovule longevity and pollen's time to germinate and reach the ovule. One approach to increase the fruit set involves promoting the growth of the pollen tubes in style and their subsequent success at reaching the egg cell in the ovule before ovule senescence. Earlier research exhibited that Put applied at bloom improved pollen tube ovule penetration and delayed ovule senescence, extending the successful pollination time of the 'Comice' pear (Pyrus communis L.) by at least 2 and $4 \mathrm{~d}$ (Crisosto et al., 1992). In the current study, in sweet cherry, 'Tieton', there was no significant difference in the period for pollen tube reaching stylar base or ovary among all treatments, although Spd and Spm treatments appeared to improve pollen tube growth at early stages after spray (Fig. 3). A high level of polyamines (PAs) plays a vital role in pollen tube growth (Gémes et al., 2016; Wu et al., 2010). Exogenous application of PAs helps in pollen maturation, its germination and tube elongation depending upon the dose of PAs (Aloisi et al., 2016, 2017). The same was also supported by our previous PAs results in 'Tieton' and 'Regina'.

Our assessment of ovule viability revealed benefits from treatment with both $\mathrm{GA}_{4 / 7}$ and 4-CPA (Fig. 4): both treatments significantly improved ovule longevity from the viability of secondary ovule. There were no recorded differences in viability of the primary ovule.
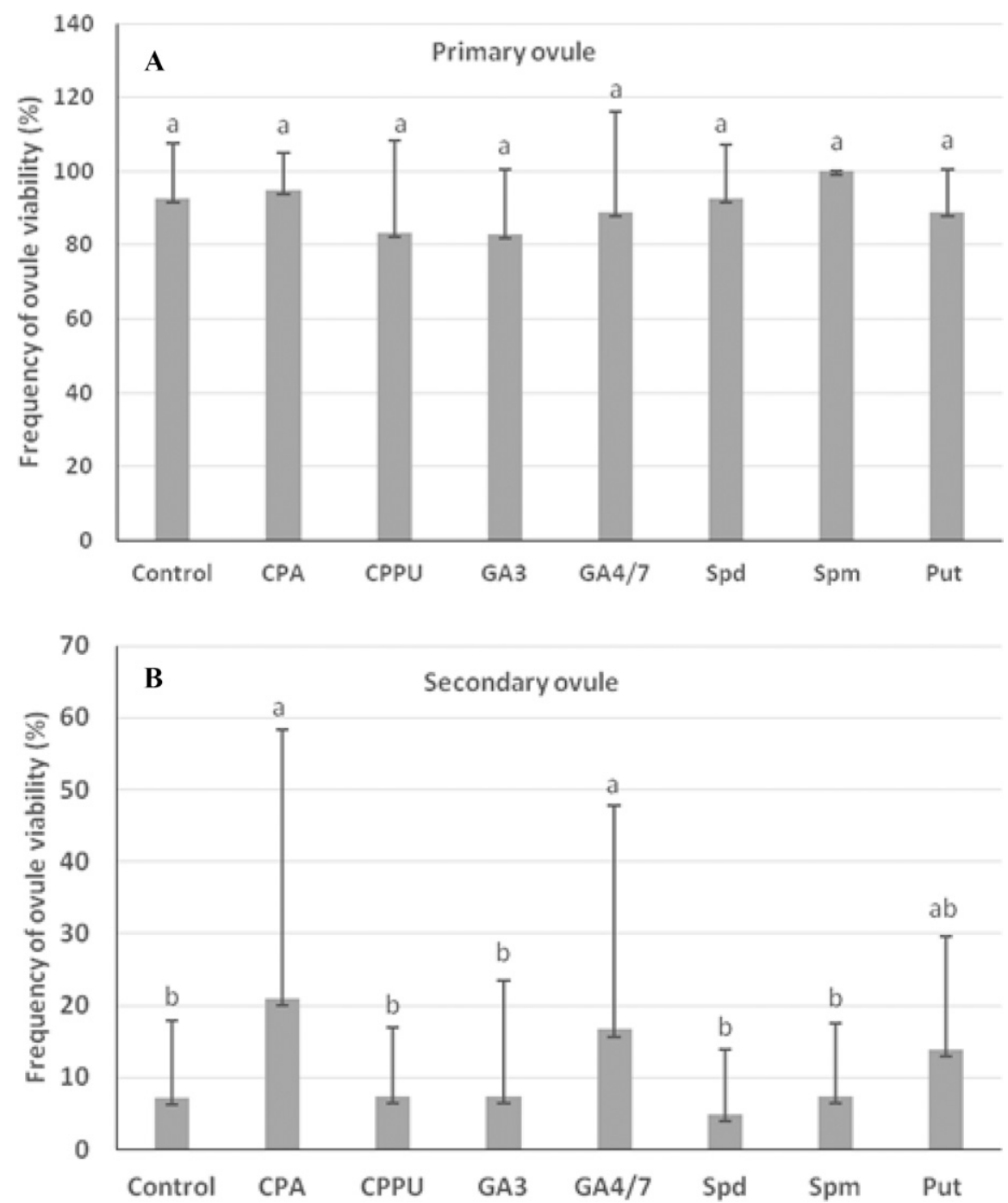

Fig. 4. Effect of foliar application of plant growth regulators at full bloom on ovule viability in sweet cherry 'Tieton'. (A) Primary ovule; (B) secondary ovule. CPA $=4$-chlorophenoxyacetic acid; $\mathrm{CPPU}=\mathrm{N}-(2-$ chloro-4-pyridyl)-N'-phenylurea; GA = gibberellin; Put = putrescine; $\mathrm{Spd}=$ triamine spermidine; $\mathrm{Spm}=$ tetraamine spermine. 

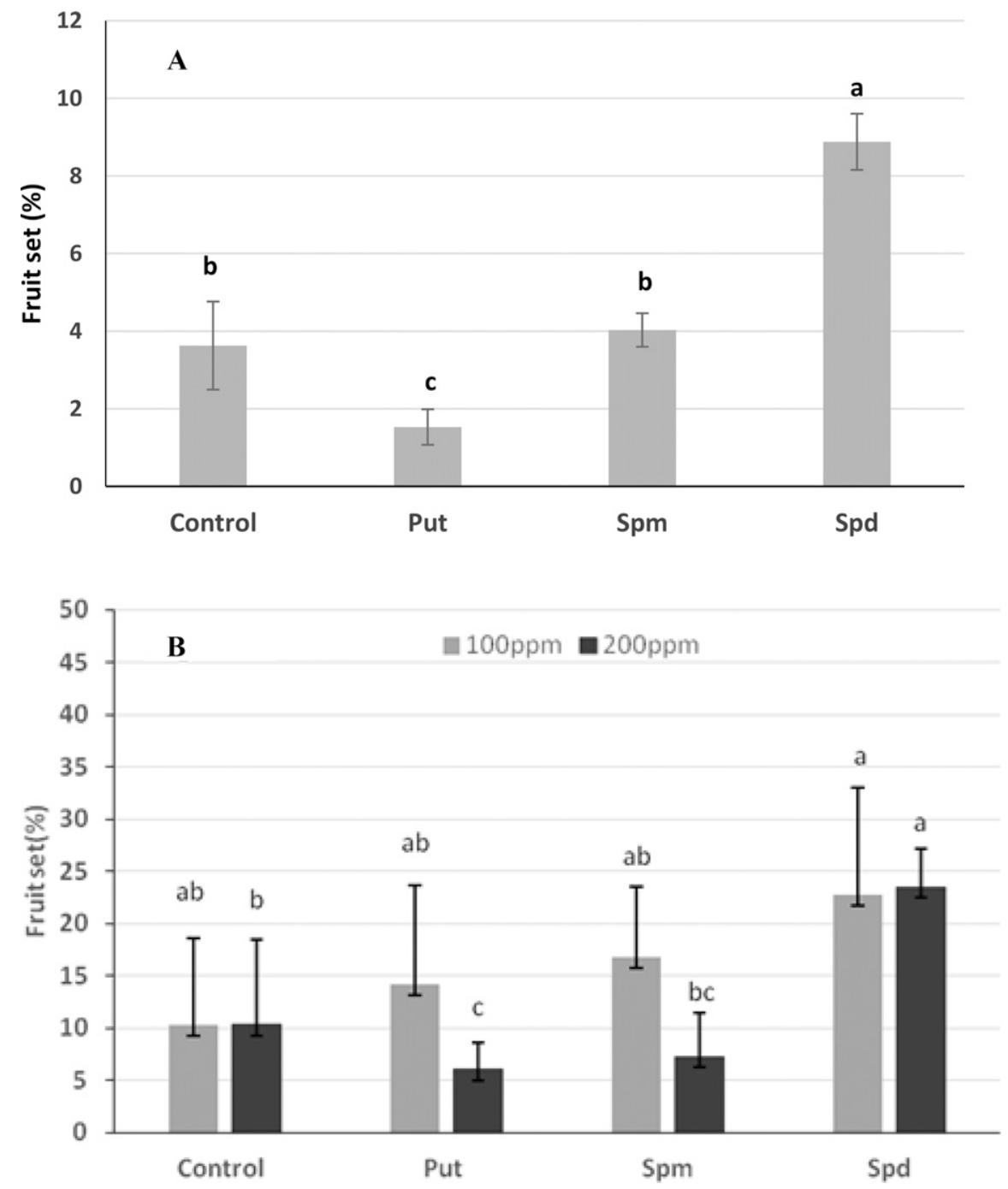

Fig. 5. Influence of plant growth regulators (PGRs) applied at full bloom on fruit set in sweet cherry 'Regina'. Data are average \pm SE. Different letters represent significant difference between PGRs at a $P$ level of 0.05 (least significant difference test). Put $=$ putrescine; $\mathrm{Spd}=$ triamine spermidine; $\mathrm{Spm}=$ tetraamine spermine.

Stösser and Anvari (1982) promoted the ovule senescence of sweet cherry ovules with gibberellic acid and benzyladenine (BA)

treatments. In our work, we saw improved 'Tieton' fruit set from treatment with $\mathrm{GA}_{3}$, CPPU, and 4-CPA (Fig. 2A), yet only 4-CPA

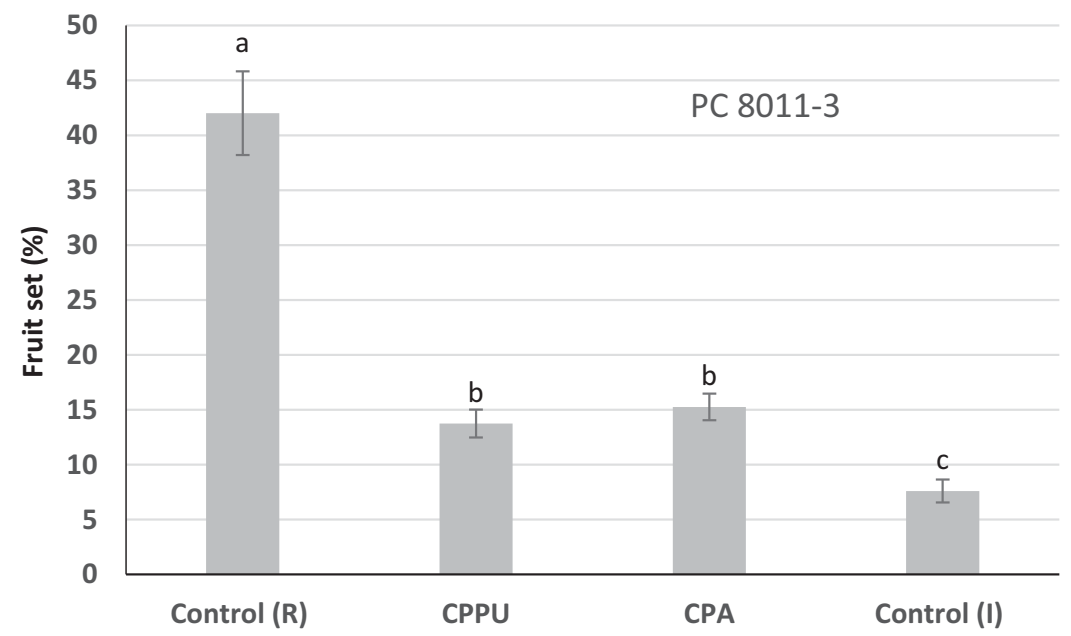

Fig. 6. Effect of foliar application of N-(2-chloro-4-pyridyl)-N'-phenylurea (CPPU) and 4-chlorophenoxyacetic acid (4-CPA) at full bloom on fruit set in sweet cherry 'PC-8011-3'. Data are average \pm SE. Different letters represent a significant difference among plant growth regulators at a $P$ level of 0.05 (least significant difference test). Control I: control interior; Control R: control roadside. appears to have influenced a component of the effective pollination period by extending ovule viability (Fig. 4). It is not clear how treatment with $\mathrm{GA}_{3}$ and CPPU improves fruit set in 'Tieton'. Further research in this area is warranted to understand better factors limiting fruit set and the physiological mechanisms for overcoming those.

\section{Fruit quality}

PGRs regulate cell development and growth through manipulating cell division and cell expansion in fruit growth in sweet cherries (Zhang and Whiting, 2011). Previous research has verified the potential for improving fruit size and quality of sweet cherry with PGRs, especially preharvest application of gibberellins $\left(\mathrm{GA}_{3}\right)$ during the stages II-III transition (Clayton et al., 2006; Facteau et al., 1985; Kappel and MacDonald, 2002, 2007; Lenahan et al., 2006; Proebsting et al., 1973; Stern et al., 2007; Zhang and Whiting, 2013). Our group evaluated a wide range of PGRs applied at critical stages of fruit development and their potential to improve fruit growth during cell division (i.e., stage I) and/or cell expansion (i.e., stage III) in sweet cherry (Zhang and Whiting, 2011). The current study explored the potential improvement of fruit quality in sweet cherries among genotypes with foliar application of PGRs applied at bloom.

Fruit growth. Fruit growth is associated with hormones produced in the ovary after fertilization. Some are important for early fruit growth and others for the entire growth period (Srivastava and Handa, 2005). Cytokinins accelerated early fruit growth rate, including CPPU, BA, and Topolin (Fig. 7A) in sweet cherry 'Bing'. The highest peak growth was observed in week third in 'Bing,' which was accelerated by Toplin and followed by TDZ, while the same increment behavior was observed in week fourth in CPPU treatment (Fig. 7A). CPPU also enhanced the fruit growth in 'Tieton' and 'PC8011-3' (Fig. 7B and C). These results illustrate the potential benefits of cytokinin to overcome the early senesces of the fertilized ovary in sweet cherry. Exogenous application of cytokinin increases hormone levels in the fertilized ovary, helping early growth in sweet cherries. The same was observed in apples and grapes (Bangerth and Schröder, 1994).

4-CPA also enhanced the fruit growth in sweet cherries and maximum growth acceleration was observed in the fourth and/or fifthweek post-treatment. The same strong support was observed for fruit growth through auxin in tomato and other species (De Jong et al., 2009). Gibberellin is applied in stone fruit production to influence fruit thinning, reduce differentiation of flower buds, influence fruit quality, delay harvest, and improve storability (Stern et al., 2007). Gibberellins also play a role in cell division and elongation in sweet cherries, and exogenous GA isomers application is a useful tool to increase fruit growth. A higher fruit growth rate was 
A

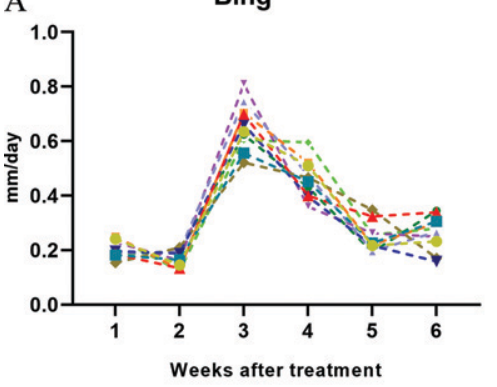

$\mathrm{C}$

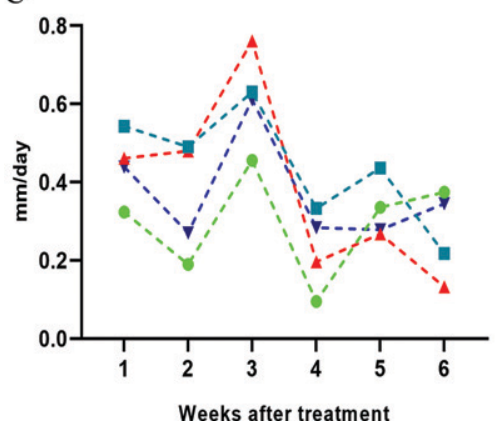

B

Tieton
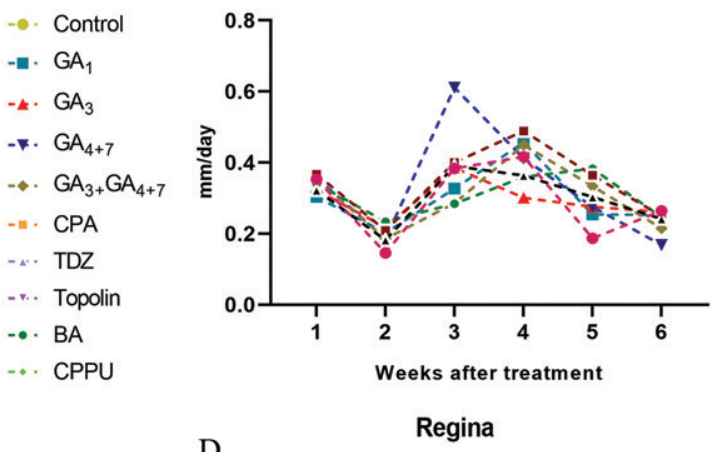

-• Control

-.. Put

-n. Spm

-๑. Spd

-↔. $\mathrm{GA}_{3}$

-F. $\mathrm{GA}_{4+7}$

- . CPPU

-․ . CPA

$\mathrm{D}$

- - Control (I)
-m. CPPU
- . CPA
-F. Control (R)

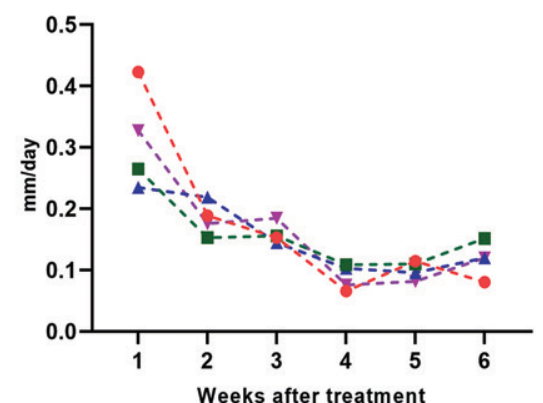

- - Contr

-n. Put

- F. Spd
-^. Spm

Fig. 7. Effects of foliar application of plant growth regulators at full bloom on fruit growth in sweet cherries (A) 'Bing', (B) 'Tieton', (C) 'PC 8011-3', and (D) 'Regina'. 4-CPA = 4-chlorophenoxyacetic acid; BA = N6-benzyladenine; $C P P U=$ N-(2-chloro-4-pyridyl)-N'-phenylurea; GA = gibberellin; Put = putrescine; $\mathrm{Spd}=$ triamine spermidine; Spm = tetraamine spermine; TDZ = N-phenyl-N'-(1, 2, 3-thiadiazol-5-yl) urea; Topolin = 6-(3-hydroxybenzylamino) purine.

observed in the second, third, and fourth week than the control in 'Bing'. GA $4 / 7$, compared with the other GA isomers, showed the highest growth rate in the second, third, and fourth week in 'Bing'. A similar growth pattern was also observed in 'Tieton'. High levels of GAs significantly reduce the early ovary senesces after fertilization. Plants use a variety of mechanisms to keep GA at a constant level (GA homeostasis). GA homeostasis can be established in plant tissues by suppressing GA biosynthesis and promoting GA catabolism. Reduced expression of the GA biosynthetic genes GA20ox and GA3ox is considered to facilitate biosynthesis suppression however elevation of catabolism (feedforward regulation) results from improved expression of the GA catabolic genes GA2ox. Exogenous application of GAs boosts the upregulation of GA20ox genes and CPS, and supports downregulation of GA3ox genes, which help the early fruit growth rate (Olimpieri et al., 2007). Polyamines are effective for growth and development in the early stage because of their direct effect on cell division and cell differentiation (Shawky, 2003). Bean plants have experienced the same phenomenon (Altman et al., 1982). Polyamines are also effective for increasing the fruit growth rate in sweet cherries. Maximum growth acceleration was observed in the second week both in 'Regina' and 'Tieton' (Fig. 7B and D). Growth promoting behavior of polyamines is just because of their cationic molecular structure, which gained the positive charge in intercellular $\mathrm{pH}$ which plays a vital role in growth and development.
Table 1. Effect of plant growth regulator application on fruit weight, firmness, total soluble solids (TSS), and color rating of sweet cherry 'Bing'.

\begin{tabular}{lcccc}
\hline Treatment & Fruit wt $(\mathrm{g})$ & Firmness $\left(\mathrm{mg} / \mathrm{mm}^{2}\right)$ & TSS (Brix) & Color $($ CTIFL) \\
\hline Control & $8.3 \mathrm{bc}$ & $188.1 \mathrm{ab}$ & $19.6 \mathrm{bcd}$ & $6.2 \mathrm{a}$ \\
$\mathrm{GA}_{1}$ & $8.4 \mathrm{abc}$ & $203.9 \mathrm{a}$ & $18.8 \mathrm{~cd}$ & $6.2 \mathrm{a}$ \\
$\mathrm{GA}_{3}$ & $9.1 \mathrm{ab}$ & $204.5 \mathrm{a}$ & $18.9 \mathrm{~cd}$ & $5.9 \mathrm{~b}$ \\
$\mathrm{GA}_{4 / 7}$ & $9.4 \mathrm{a}$ & $193.0 \mathrm{ab}$ & $18.1 \mathrm{de}$ & $6.1 \mathrm{a}$ \\
$\mathrm{GA}_{3}+\mathrm{GA}_{4 / 7}$ & $8.1 \mathrm{bc}$ & $195.6 \mathrm{ab}$ & $16.5 \mathrm{e}$ & $4.4 \mathrm{c}$ \\
$4-\mathrm{CPA}$ & $8.8 \mathrm{abc}$ & $194.0 \mathrm{ab}$ & $20.1 \mathrm{bcd}$ & $6.1 \mathrm{a}$ \\
TDZ & $8.1 \mathrm{bc}$ & $175.2 \mathrm{~b}$ & $22.9 \mathrm{a}$ & $6.2 \mathrm{a}$ \\
Topolin & $7.9 \mathrm{c}$ & $194.4 \mathrm{ab}$ & $21.5 \mathrm{ab}$ & $6.0 \mathrm{a}$ \\
BA & $8.1 \mathrm{bc}$ & $189.3 \mathrm{ab}$ & $20.5 \mathrm{bc}$ & $6.1 \mathrm{a}$ \\
CPPU & $8.3 \mathrm{bc}$ & $195.2 \mathrm{ab}$ & $18.4 \mathrm{cde}$ & $5.8 \mathrm{~b}$ \\
\hline
\end{tabular}

${ }^{\mathrm{z}}$ Color rating: the higher number indicates dark color. CTIFL $=$ Center Technique Interprofessional des Fruit et Legumes.

Means followed by the same letters are not significantly different $(P=0.05)$ by Duncan's new multiple range test.

4-CPA = 4-chlorophenoxyacetic acid; $\mathrm{BA}=\mathrm{N6}$-benzyladenine; $\mathrm{CPPU}=\mathrm{N}-(2$-chloro-4-pyridyl)-N'phenylurea; $\mathrm{GA}=$ gibberellin; TDZ $=\mathrm{N}-$ phenyl-N'-(1, 2, 3-thiadiazol-5-yl) urea; Topolin = 6-(3hydroxybenzylamino) purine.

Table 2. Effect of plant growth regulator application on fruit weight, firmness, total soluble solids (TSS), and color rating of sweet cherry 'Tieton'.

\begin{tabular}{lcccc}
\hline Treatment & Fruit wt $(\mathrm{g})$ & Firmness $\left(\mathrm{mg} / \mathrm{mm}^{2}\right)$ & TSS $($ Brix $)$ & Color $(\mathrm{CTIFL})^{\mathrm{z}}$ \\
\hline Control & $6.1 \mathrm{c}$ & $187.4 \mathrm{~b}$ & $13.6 \mathrm{~b}$ & $5.3 \mathrm{abc}$ \\
GA3 & $6.4 \mathrm{c}$ & $211.9 \mathrm{a}$ & $14.0 \mathrm{ab}$ & $4.5 \mathrm{c}$ \\
GA4/7 & $8.8 \mathrm{a}$ & $187.6 \mathrm{~b}$ & $15.5 \mathrm{ab}$ & $5.7 \mathrm{a}$ \\
4-CPA & $6.3 \mathrm{c}$ & $172.5 \mathrm{~cd}$ & $14.3 \mathrm{ab}$ & $4.6 \mathrm{bc}$ \\
CPPU & $6.1 \mathrm{c}$ & $162.8 \mathrm{~d}$ & $14.7 \mathrm{ab}$ & $5.7 \mathrm{a}$ \\
Put & $6.1 \mathrm{c}$ & $183.9 \mathrm{bc}$ & $13.7 \mathrm{~b}$ & $5.4 \mathrm{abc}$ \\
Spd & $6.8 \mathrm{bc}$ & $169.1 \mathrm{~cd}$ & $13.9 \mathrm{ab}$ & $5.0 \mathrm{abc}$ \\
Spm & $7.8 \mathrm{ab}$ & $180.4 \mathrm{bc}$ & $15.9 \mathrm{a}$ & $5.6 \mathrm{ab}$ \\
\hline
\end{tabular}

${ }^{\mathrm{z}}$ Color rating: the higher number indicates dark color. CTIFL $=$ Center Technique Interprofessional des Fruit et Legumes.

Means followed by the same letters are not significantly different $(P=0.05)$ by Duncan's new multiple range test. 4-CPA $=4$-chlorophenoxyacetic acid; CPPU $=\mathrm{N}$-(2-chloro-4-pyridyl)-N'-phenylurea; GA $=$ gibberellin; Put = putrescine; $\mathrm{Spd}=$ triamine spermidine; $\mathrm{Spm}=$ tetraamine spermine. 
Fruit weight and size. For sweet cherries, fruit size remains the most crucial fruit quality attribute, and developing pragmatic strategies for improving fruit size is of great interest. Previously, preharvest applications of GA showed a positive response on fruit weight enhancement in sweet cherries (Canli et al., 2015; Zhang and Whiting, 2011, 2013). GAs also produced a positive impact on fruit

weight: a 44\% gain was observed in 'Tieton', whereas 'Bing' gained $13.2 \%$ additional weight compared with control when both were treated with $\mathrm{GA}_{4 / 7}$ at bloom stage (Tables 1 and 2). A single application of $\mathrm{GA}_{3}$ increased fruit weight by $9.6 \%$ in 'Bing' and $4.9 \%$ in 'Tieton'. Auxins improve the early growth in fruit development but do not affect the final fruit weight. 4-CPA did not show a statistical

Table 3. Effect of plant growth regulator application on fruit weight, firmness, total soluble solids (TSS), and color rating of sweet cherry 'PC 8011-3'.

\begin{tabular}{lcccc}
\hline Treatment & Fruit wt $(\mathrm{g})$ & Firmness $\left(\mathrm{mg} / \mathrm{mm}^{2}\right)$ & TSS $($ Brix $)$ & Color $(\mathrm{CTIFL})^{\mathrm{z}}$ \\
\hline Control I & $12.1 \mathrm{bc}$ & $298.2 \mathrm{~b}$ & $20.8 \mathrm{ab}$ & $4.3 \mathrm{a}$ \\
CPPU & $13.8 \mathrm{a}$ & $317.8 \mathrm{a}$ & $21.9 \mathrm{a}$ & $4.8 \mathrm{a}$ \\
4-CPA & $13.1 \mathrm{ab}$ & $300.2 \mathrm{~b}$ & $20.7 \mathrm{ab}$ & $5.2 \mathrm{a}$ \\
Control R & $10.471 \mathrm{c}$ & $292.7 \mathrm{~b}$ & $19.1 \mathrm{~b}$ & $4.4 \mathrm{a}$ \\
\hline
\end{tabular}

${ }^{\mathrm{z}}$ Color rating: the higher number indicates dark color. CTIFL $=$ Center Technique Interprofessional des Fruit et Legumes.

Means followed by the same letters are not significantly different $(P=0.05)$ by Duncan's new multiple range test.

Control $\mathrm{I}=$ control interior; Control $\mathrm{R}=$ control roadside; 4-CPA = 4-chlorophenoxyacetic acid; $\mathrm{CPPU}=\mathrm{N}-(2-$ chloro-4-pyridyl)-N'-phenylurea.

Table 4. Effect of plant growth regulator application on fruit weight, firmness, total soluble solids (TSS), and color rating of sweet cherry 'Regina'.

\begin{tabular}{lcccc}
\hline Treatment & Fruit $\mathrm{wt}(\mathrm{g})$ & Firmness $\left(\mathrm{mg} / \mathrm{mm}^{2}\right)$ & TSS $($ Brix $)$ & Color $(\mathrm{CTIFL})^{\mathrm{z}}$ \\
\hline Control & $7.2 \mathrm{a}$ & $296.1 \mathrm{~b}$ & $20.1 \mathrm{a}$ & $4.8 \mathrm{a}$ \\
Put & $7.9 \mathrm{a}$ & $301.2 \mathrm{~b}$ & $21.1 \mathrm{~b}$ & $4.3 \mathrm{a}$ \\
Spd & $7.2 \mathrm{a}$ & $301.7 \mathrm{~b}$ & $21.1 \mathrm{~b}$ & $4.7 \mathrm{a}$ \\
Spm & $9.1 \mathrm{~b}$ & $312.7 \mathrm{a}$ & $20.3 \mathrm{a}$ & $4.2 \mathrm{a}$ \\
\hline
\end{tabular}

${ }^{\mathrm{z}}$ Color rating: the higher number indicates dark color. CTIFL $=$ Center Technique Interprofessional des Fruit et Legumes.

Means followed by the same letters are not significantly different $(P=0.05)$ by Duncan's new multiple range test.

Put $=$ putrescine; $\mathrm{Spd}=$ triamine spermidine; $\mathrm{Spm}=$ tetraamine spermine. increment in fruit weight in either 'Bing' or 'Tieton', but mild enhancement was observed up to $8 \%$ in 'PC 8011-3'.

Our previous report in Japanese pear confirmed that 4-CPA also stimulated higher fruit growth rates at stage I and stage II and fruit color development but did not improve final fruit size (Zhang and Whiting, 2011). However, the cytokinin treatments showed no positive response for fruit weight except for a $14 \%$ enhancement by CPPU in 'PC 8011-3' (Table 3) and kiwifruit, grape, and pear (Bangerth and Schröder, 1994; Patterson et al., 1993). Polyamines are considered antiethylene substances (Apelbaum et al., 1981) and have the properties of growth promoters (Rugini et al., 1985). Spm, compared with Put and Spd, boosted fruit weight by $27 \%$ and $24 \%$ in both 'Tieton' and 'Regina', respectively, compared with the control (Tables 2 and 4). Furthermore, total harvested fruits were also categorized in row size for fruit size evaluation. $\mathrm{GA}_{3}$ applied at bloom stage was found most effective for fruit size enhancement in 'Bing' with $3.3 \%$ at 9.5 row size, $20 \%$ at 10 row size, $40 \%$ attained at 10.5 row size, but only $1.3 \%, 15.3 \%$, and $32.6 \%$ in each category for the control (Fig. 8 ). Remarkable enhancement can be observed in each category when 'Bing' was treated with GAs compared with control. Berry size enhancement was also found in grapes when it treated with GAs (Stewart et al., 1958; Weaver and McCune, 1959). $\mathrm{GA}_{4 / 7}$ has the highest percentage of $73 \%$ fruit above 10.5 row size, compared with only $13.5 \%$ in control in 'Tieton'. Both BA and TDZ showed a $15 \%$ to $30 \%$ higher percentage of fruit above

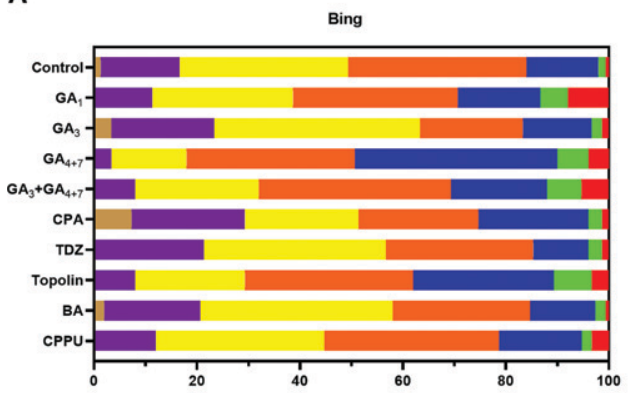

C

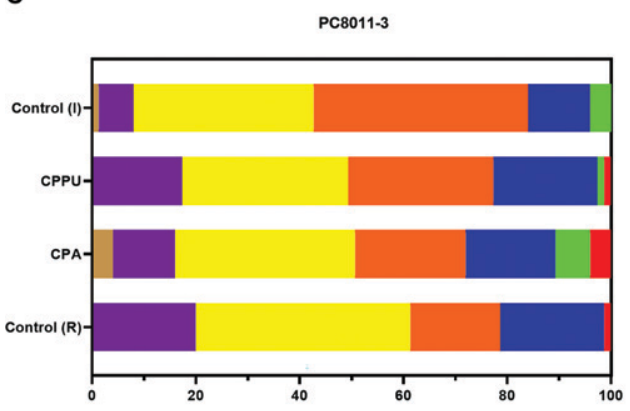

B

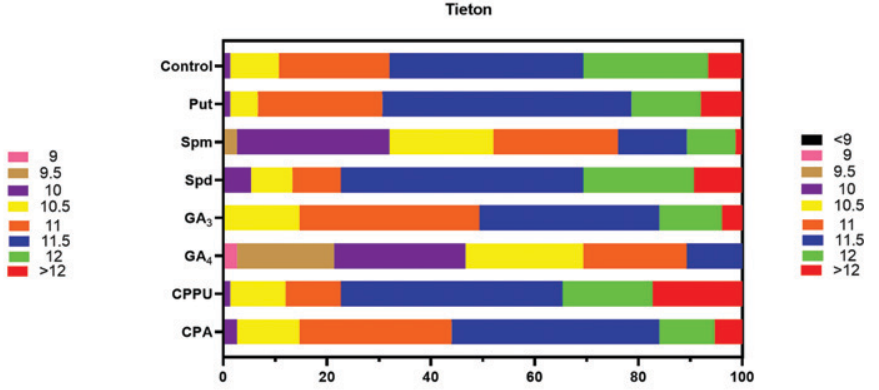

D

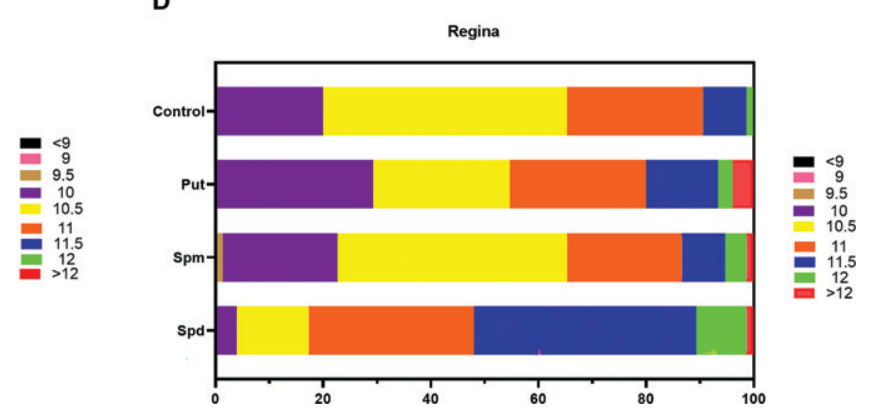

Fig. 8. Effects of foliar application of plant growth regulators at full bloom on fruit size distribution in sweet cherries (A) 'Bing', (B) 'Tieton', (C) 'PC 8011-3', and (D) 'Regina'. 

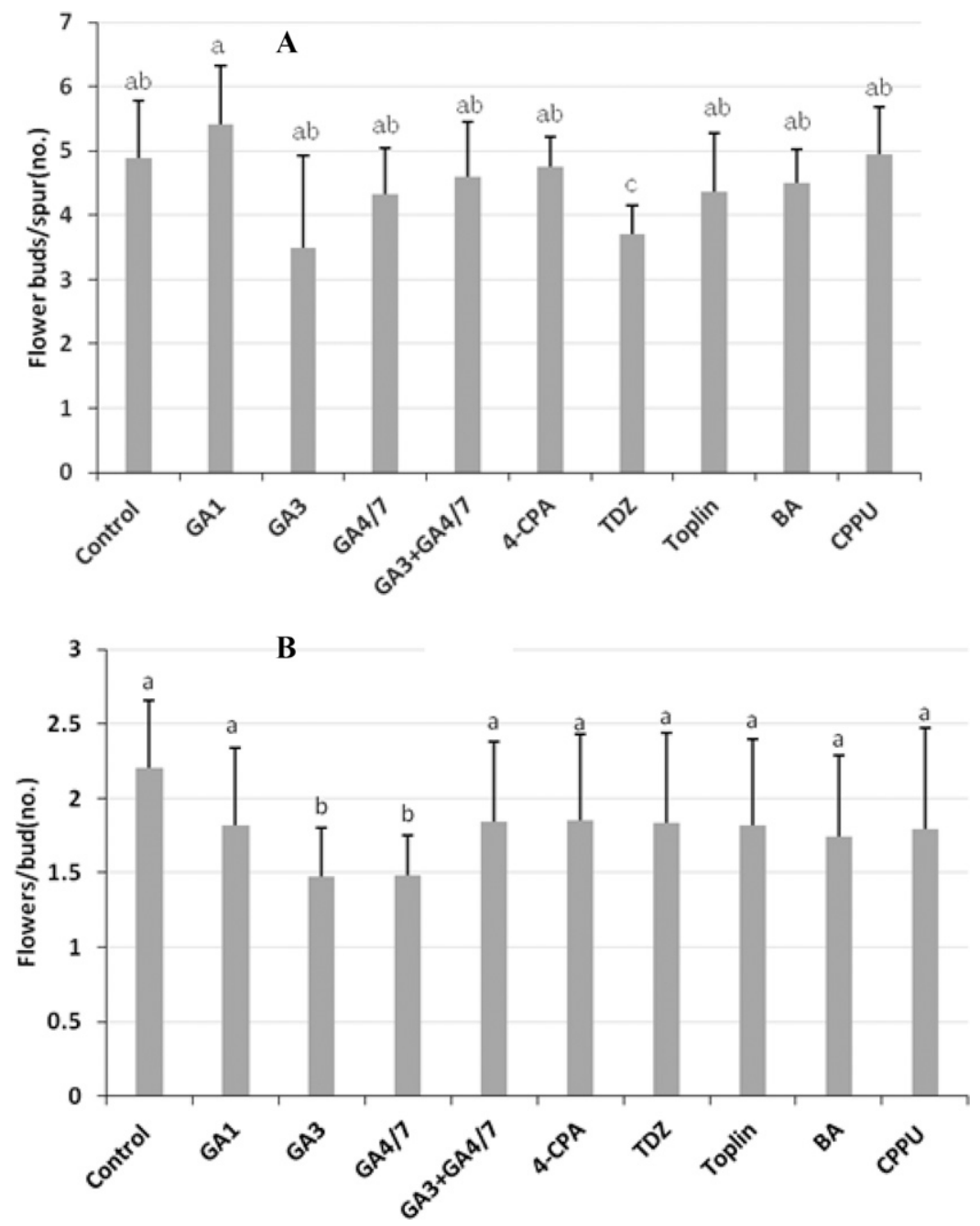

Fig. 9. Effects of foliar application of plant growth regulators on return bloom and flower bud development in sweet cherry 'Bing'.

row 10.5 than those in both CPPU and Topolin treatments (Fig. 8). Additional stimulation of cell division and final fruit size enhancement was examined when the apple was treated with BA (Stern et al., 2003). 4-CPA showed a high percentage above row 10.5 in both 'Bing' (52\%) and 'PC8011-3' (50\%), but only $18 \%$ in 'Tieton'. The same results were confirmed in peaches treated with 4CPA (Crane, 1953). Put slightly increased fruit size in 'Regina', and $29.33 \%$ fruit were found in the row 10 category, which was $9.33 \%$ greater compared with control. Spm slightly affected fruit size in 'Regina' but greatly affected it in 'Tieton' with $29.3 \%$ fruit in row 10.5 category, which was $20 \%$ more than the control.

Total soluble solids, firmness, and color. Previous studies showed that GAs alone can improve fruit size and delay fruit maturation and exocarp coloration (Clayton et al., 2006; Cline and Trought, 2007; Kappel and MacDonald, 2002; Zhang and Whiting, 2011, 2013), yet little research has investigated the effects of PGRs applied during flowering on fruit quality. Applied at bloom, both $\mathrm{GA}_{1}$ and $\mathrm{GA}_{3}$ alone increased fruit firmness and reduced soluble solids content (TSS) in
'Bing', but $\mathrm{GA}_{3}$ rather than $\mathrm{GA}_{1}$ delay the color development (Tables 1 and 2). $\mathrm{GA}_{3}$ also delayed the color maturation and gave additional time to the fruit to mature compared with control in sweet cherry (Choi et al., 2002), whereas exogenous application of $\mathrm{GA}_{3}$ also increased the firmness and reduced the TSS in 'Sweetheart' and 'Skeena' (Einhorn et al., 2013). $\mathrm{GA}_{4 / 7}$ applied alone did not affect the fruit firmness and exocarp red coloration, but reduced TSS in 'Bing' and 'Tieton'. Furthermore, $\mathrm{GA}_{4 / 7}$, when combined with $\mathrm{GA}_{3}$, reduced TSS and delayed the color development in 'Bing'. Foliar application of cytokinins did not affect fruit firmness except for TDZ with reduced firmness in 'Bing'. On the contrary, CPPU reduced TSS and delayed color development. However, the other cytokinins did not affect the color development, whereas both TDZ and Topolin increase fruit TSS except BA treatment in 'Bing'. 4-CPA stimulated higher fruit growth rates at stage I and II and fruit color development, but it did not improve final fruit size (Zhang and Whiting, 2011). Herein, 4-CPA applied at bloom has no effect on fruit firmness, TSS, or color development in either 'Bing' or 'PC8011-3', but it reduced fruit firmness and increased TSS with delayed fruit color development in 'Tieton'. Polyamines do not affect fruit color development in both 'Tieton' and 'Regina'. Sixteen percent $(\mathrm{Spm})$ and $6 \%(\mathrm{Spd})$ enhancement were observed compared with control in 'Tieton' and 'Regina', respectively.

PGRs vs. return bloom. Floral induction is a process that is controlled, in large part, by endogenous hormones. Exogenous application of various PGRs can significantly affect sweet cherry floral induction and bloom density in the subsequent season (Lenahan et al., 2006). There are two key components of flower density for sweet cherries: the number of floral buds per spur and the number of flowers within each bud. In the current study, PGRs had variable effects on flower buds/ spur and flowers/bud of 'Bing'. Among GA isomers, $\mathrm{GA}_{1}$ has the potential to increase flower buds/spur, whereas $\mathrm{GA}_{3}$ significantly reduced flower buds/spur, and there was no significant difference between the control and $\mathrm{GA}_{4 / 7}$ along with $\mathrm{GA}_{3}+\mathrm{GA}_{4 / 7}$ treatments (Fig. 9A). GA $\mathrm{GA}_{4 / 7}$ also did not affect return bloom in 'Golden Delicious' (McArtney et al., 2007). Among cytokinins, BA, CPPU, and Toplin did not affect flower buds/spur. Cytokinin also did not affect pear for return bloom when tested for fruit set (Flaishman et al., 2001). TDZ treatment significantly reduced flower buds/spur by $\approx 20 \%$ (Fig. 9A). Also, there was no significant difference between 4-CPA and the control.

Analyses of the flower number per bud after PGR application shows that the single application of both $\mathrm{GA}_{3}$ and $\mathrm{GA}_{4 / 7}$ significantly reduced the flower number per bud; however, none of the other treatments had any positive effect on the number of flowers per bud. Combined, the flowering potential per spur for untreated control was ca. 11 flowers (i.e., 4.9 buds per spur $\times 2.2$ flowers per bud). Treatment with $\mathrm{GA}_{3}, \mathrm{GA}_{4 / 7}$, and TDZ would have predicted flower density of $\approx 5.1$, 6.0 , and 6.7 flowers per spur, respectively, which are significant reductions compared with control (Fig. 9B). Interestingly, $\mathrm{GA}_{3}$ and $\mathrm{GA}_{4 / 7}$ treatments appear to reduce flower density, but their combination did not. Further studies of PGR effects on return bloom density are warranted; treatments that reduce yield potential by more than $50 \%$ (e.g., $\mathrm{GA}_{3}$ ) may not be commercially practical.

Excessive fruit set causes a high yield of poor-quality fruit, and inadequate fruit set causes economic losses in sweet cherries. The current study shows that foliar application of PGRs provides a potential practical approach to optimize fruit set and improve fruit quality in sweet cherries. The results show that BA, Topolin, and TDZ could be the options for fruit thinners, and the application of $\mathrm{GA}_{3}$ or $\mathrm{GA}_{4 / 7}$ alone results in off-year fruiting. Although CPPU could increase fruit set, it usually delays fruit maturation and color development. Foliar application of 4CPA significantly improved fruit set and fruit size in 'Bing'. Compared with other isomers of GA alone, the combination of $\mathrm{GA}_{3}$ and $\mathrm{GA}_{4 / 7}$ improves fruit set more effectively. 
$\mathrm{GA}_{4 / 7}$ and 4-CPA also boosted ovule longevity, which had been linked to a higher fruit set and better fruit quality. The response of sweet cherry fruits to polyamine spraying depended on the properties of the cultivars and the concentration.

\section{Literature Cited}

Aloisi, I., G. Cai, C. Faleri, L. Navazio, D. Serafini-Fracassini, and S. Del Duca. 2017. Spermine regulates pollen tube growth by modulating $\mathrm{Ca} 2+$-dependent actin organization and cell wall structure. Front. Plant Sci. 8:1701, doi: https://doi.org/10.3389/fpls.2017.01701.

Aloisi, I., G. Cai, D. Serafini-Fracassini, and S. Del Duca. 2016. Polyamines in pollen: From microsporogenesis to fertilization. Front. Plant Sci. 7:155, doi: https://doi.org/10.3389/fpls.2016.00155.

Altman, A., R. Friedman, D. Amir, and N. Levin. 1982. Polyamine effects and metabolism in plants under stress conditions.

Apelbaum, A., A.C. Burgoon, J.D. Anderson, M. Lieberman, R. Ben-Arie, and A.K. Mattoo. 1981. Polyamines inhibit biosynthesis of ethylene in higher plant tissue and fruit protoplasts. Plant Physiol. 68:453-456.

Bangerth, F. and M. Schroder. 1994. Strong synergistic effects of gibberellins with the synthetic cytokinin N-(2-chloro-4-pyridyl)-N-phenylurea on parthenocarpic fruit set and some other fruit characteristics of apple. Plant Growth Regulat. 15:293-302.

Canli, F.A., M. Sahin, S. Ercisli, O. Yilmaz, N. Temurtas, and M. Pektas. 2015. Harvest and postharvest quality of sweet cherry are improved by pre-harvest benzyladenine and benzyladenine plus gibberellin applications. J. Appl. Bot. Food Quality 88.

Cano-Medrano, R. and R.L. Darnell. 1998. Effect of GA3 and pollination on fruit set and development in rabbiteye blueberry. HortScience 33:632-635.

Carrera, E., O. Ruiz-Rivero, L.E.P. Peres, A. Atares, and J.L. Garcia-Martinez. 2012. Characterization of the procera tomato mutant shows novel functions of the SIDELLA protein in the control of flower morphology, cell division and expansion, and the auxin-signaling pathway during fruit-set and development. Plant Physiol. 160:1581-1596, doi: https://doi.org/10.1104/ pp.112.204552.

Choi, C., P. Wiersma, P. Toivonen, and F. Kappel. 2002. Fruit growth, firmness and cell wall hydrolytic enzyme activity during development of sweet cherry fruit treated with gibberellic acid (GA3). J. Hort. Sci. Biotechnol. 77:615-621, doi: https://doi.org/10.1080/14620316.2002.11511547.

Clayton, M., W.V. Biasi, I.T. Agar, S.M. Southwick, and E.J. Mitcham. 2006. Sensory quality of 'Bing' sweet cherries following preharvest treatment with hydrogen cyanamide, calcium ammonium nitrate, or gibberellic acid. HortScience 41:745-748.

Cline, J. and M. Trought. 2007. Effect of gibberellic acid on fruit cracking and quality of Bing and Sam sweet cherries. Can. J. Plant Sci. 87:545-550.

Costa, G., R. Baraldi, and N. Bagni. 1983. Influence of putrescine on fruit-set of apple (cv Ruby Spur). Flowering and Fruit Set in Fruit Trees 149:189-196.

Crane, J.C. 1953. Further responses of the apricot to 2, 4, 5-trichlorophenoxyacetic acid application. Proc. Amer. Soc. Hort. Sci, Amer. Soc. Hort. Sci., p. 163-174.

Crane, J.C., C.A. Rebeiz, and R. Campbell. 1961. Gibberellin-induced parthenocarpy in the $\mathrm{JH}$
Hale peach and the probable cause of 'button' production. Proc. Amer. Soc. Hort. Sci., p. $111-118$.

Crisosto, C.H., D.A. Grantz, and F. Meinzer. 1992. Effects of water deficit on flower opening in coffee (Coffea arabica L.). Tree Physiol. 10:127-139.

Cubero, J., F. Toribio, M. Garrido, M. Hernández, J. Maynar, C. Barriga, and A. Rodríguez. 2010. Assays of the amino acid tryptophan in cherries by HPLC-fluorescence. Food Anal. Methods 3:36-39.

De Jong, M., C. Mariani, and W.H. Vriezen. 2009. The role of auxin and gibberellin in tomato fruit set. J. Expt. Bot. 60:1523-1532, doi: https://doi.org/10.1093/jxb/erp094.

Einhorn, T.C., Y. Wang, and J. Turner. 2013. Sweet cherry fruit firmness and postharvest quality of late-maturing cultivars are improved with low-rate, single applications of gibberellic acid. HortScience 48:1010-1017, doi: https:// doi.org/10.21273/HORTSCI.48.8.1010.

Facteau, T., K. Rowe, and N. Chestnut. 1985. Firmness of sweet cherry fruit following multiple applications of gibberellic acid. J. Amer. Soc. Hort. Sci. 110:775-777.

Flaishman, M., A. Amihai Shargal, and S. Raphael. 2001. The synthetic cytokinin CPPU increases fruit size and yield of 'Spadona' and 'Costia' pear (Pyrus communis L.). J. Hort. Sci. Biotechnol. 76:145-149, doi: https://doi. org/10.1080/14620316.2001.11511341.

Garrido, M., J. Espino, A.F. Toribio-Delgado, J. Cubero, J.I. Maynar-Mariño, C. Barriga, S.D. Paredes, and A.B. Rodríguez. 2012. A Jerte Valley cherry-based product as a supply of tryptophan. Intl. J. Tryptophan Res. 5:S9394.

Gémes, K., Y.J. Kim, K.Y. Park, P.N. Moschou, E. Andronis, C. Valassaki, A. Roussis, and K.A. Roubelakis-Angelakis. 2016. An NADPH-oxidase/polyamine oxidase feedback loop controls oxidative burst under salinity. Plant Physiol. 172:1418-1431, doi: https://doi.org/10.1104/ pp.16.01118.

Gemici, M., T. Bengü, and T. Kit. 2006. Effects of 2, 4-D and 4-CPA on yield and quality of the tomato, Lycopersicon esculentum Miller. J. Faculty Sci. 29:24-32.

Greene, D.W. 1988. Regulation of fruit set in tree fruits with plant growth regulators. Presented at the ISHS Acta Horticulturae 239: VI International Symposium on Growth Regulators in Fruit Production. doi: https://doi.org/10.17660/ ActaHortic.1989.239.51

Holzschuh, A., J.-H. Dudenhöffer, and T. Tscharntke. 2012. Landscapes with wild bee habitats enhance pollination, fruit set and yield of sweet cherry. Biol. Conserv. 153:101-107.

Isaacs, R. and A.K. Kirk. 2010. Pollination services provided to small and large highbush blueberry fields by wild and managed bees. J. Appl. Ecol. 47:841-849

Kappel, F. and R. MacDonald. 2007. Early gibberellic acid sprays increase firmness and fruit size of 'Sweetheart'sweet cherry. J. Amer. Pomol. Soc. 61:38.

Kappel, F. and R.A. MacDonald. 2002. Gibberellic acid increases fruit firmness, fruit size, and delays maturity of 'Sweetheart' sweet cherry. J. Amer. Pomol. Soc. 56:219.

Kondo, S., Y. Hayata, and N. Iwasaki. 1998. Effects of indole-3-acetic acid and gibberellins on fruit development and maturation of sweet cherries.

Lenahan, O.M., M.D. Whiting, and D.C. Elfving. 2006. Gibberellic acid inhibits floral bud induction and improves 'Bing' sweet cherry fruit quality. HortScience 41:654-659.
McArtney, S., D. Unrath, J. Obermiller, and A. Green. 2007. Naphthaleneacetic acid, ethephon, and gibberellin A4 + A7 have variable effects on flesh firmness and return bloom of apple. HortTechnology 17:32-38, doi: https://doi.org/ 10.21273/HORTTECH.17.1.32.

McCune, L.M., C. Kubota, N.R. Stendell-Hollis, and C.A. Thomson. 2010. Cherries and health: A review. Crit. Rev. Food Sci. Nutr. 51:1-12.

Misra, L. and V. Sharma. 1972. Effect of growth regulating substances on the control of flowering and fruit setting in sweet cherry cultivar Black Heart. Indian J. Hort. 29:292-297.

Modlibowska, I. 1972. The effect of gibberellins and cytokinins on fruit development of Bramley's Seedling apple. J. Hort. Sci. 47:337-340.

Olimpieri, I., F. Siligato, R. Caccia, G.P. Soressi, A. Mazzucato, L. Mariotti, and N. Ceccarelli. 2007. Tomato fruit set driven by pollination or by the parthenocarpic fruit allele are mediated by transcriptionally regulated gibberellin biosynthesis. Planta 226:877-888.

Olmstead, R.G., L. Bohs, H.A. Migid, E. SantiagoValentin, V.F. Garcia, and S.M. Collier. 2008 A molecular phylogeny of the Solanaceae. Taxon 57:1159-1181.

Patterson, K., K. Mason, and K. Gould. 1993. Effects of CPPU (N-(2-chloro-4-pyridyl)-N'phenylurea) on fruit growth, maturity, and storage quality of kiwifruit. N.Z. J. Crop Hort. Sci. 21:253-261.

Proebsting, E., G. Carter, and H. Mills. 1973. Quality improvement in canned rainier cherries $(P$. avium L.) with gibberellic-acid. J. Amer. Soc. Hort. Sci. 98:334-336.

Quero-Garcia, J., A. Fodor, A. Reignier, G. Capdeville, J. Joly, Y. Tauzin, L. Fouilhaux, and E. Dirlewanger. 2014. QTL detection of important agronomic traits for sweet cherry breeding. Acta Hort. 1020:57-64.

Rebeiz, C.A. and J.C. Crane. 1961. Growth regulator-induced parthenocarpy in the Bing cherry 78 .

Rugini, E., G. Bongi, and M. Mencuccini. 1985. Effect of putrescine, 1-arginine and cobalt on fruit set, ethylene content and apparent parthenocarpy in olive (Olea europaea L.) In V International Symposium on Growth Regulators in Fruit Production 179 (p. 365-368).

Ryugo, K. 1988. Fruit culture: Its science and art. John Wiley and Sons.

Saleem, B.A., A.U. Malik, R. Anwar, and M. Farooq. 2006. Exogenous application of polyamines improves fruit set, yield and quality of sweet oranges. 774:187-194, doi: https://doi. org/10.17660/ActaHortic.2008.774.23.

Shawky, N. 2003. Physiological studies on the effect of salinity, ascorbic acid and putrescine on sweet pepper plant. Ph.D. Thesis, Dept. of Agr. Bot., Faculty of Agr. Univ. of Cairo.

Shiozaki, S., T. Miyagawa, T. Ogata, S. Horiuchi, and K. Kawase. 1997. Differences in cell proliferation and enlargement between seeded and seedless grape berries induced parthenocarpically by gibberellin. J. Hort. Sci. 72:705-712.

Singh, Z. and L. Singh. 1995. Increased fruit set and retention in mango with exogenous application of polyamines. J. Hort. Sci. 70:271-277, doi: https:// doi.org/10.1080/14620316.1995.11515297.

Srivastava, A. and A.K. Handa. 2005. Hormonal regulation of tomato fruit development: A molecular perspective. J. Plant Growth Regul. 24:67-82.

Stern, R.A., R. Ben-Arie, O. Neria, and M. Flaishman. 2003. CPPU and BA increase fruit size of 'Royal Gala' (Malus domestica) apple in a warm climate. J. Hort. Sci. Biotechnol. 78:297-302. 
Stern, R.A., M. Flaishman, S. Applebaum, and R. Ben-Arie. 2007. Effect of synthetic auxins on fruit development of 'Bing' cherry (Prunus avium L.). Scientia Hort. 114:275-280, doi: https://doi.org/10.1016/j.scienta.2007. 07.010 .

Stewart, W., D. Halsey, and F. Ching. 1958. Effect of potassium salt of gibberellic acid on fruit growth of Thompson seedless grapes.

Stösser, R. and S. Anvari. 1982. On the senescence of ovules in cherries. Scientia Hort. 16:29-38.

Usenik, V., D. Kastelec, and F. Štampar. 2005. Physicochemical changes of sweet cherry fruits related to application of gibberellic acid. Food Chem. 90:663-671.

Weaver, R. and S. McCune. 1959. Effect of gibberellin on seedless Vitis vinifera. Hilgardia 29:247-275.
Weaver, R.J., J. Van Overbeek, and R.M. Pool. 1965. Induction of fruit set in Vitis vinifera L. by a kinin. Nature 206:952.

Webster, A. 1984. Plant growth regulator sprays to delay the blossoming of Victoria plum. J. Hort. Sci. 59:377-386.

Whiting, M.D. and G.A. Lang. 2004. 'Bing' sweet cherry on the dwarfing rootstock 'Gisela 5': thinning affects fruit quality and vegetative growth but not net $\mathrm{CO} 2$ exchange. J. Amer. Soc. Hort. Sci. 129:407-415.

Wu, J., Z. Shang, J. Wu, X. Jiang, P.N. Moschou, W. Sun, K.A. Roubelakis-Angelakis, and S. Zhang. 2010. Spermidine oxidase-derived $\mathrm{H}_{2} \mathrm{O}_{2}$ regulates pollen plasma membrane hyperpolarization-activated $\mathrm{Ca}^{2+}$-permeable channels and pollen tube growth. Plant J. 63:1042-1053, doi: https://doi.org/ 10.1111/j.1365-313X.2010.04301.x.
Zhang, C., K. Tanabe, F. Tamura, A. Itai, and M. Yoshida. 2007. Roles of gibberellins in increasing sink demand in Japanese pear fruit during rapid fruit growth. Plant Growth Regulat. 52:161-172.

Zhang, C. and M. Whiting. 2013. Plant growth regulators improve sweet cherry fruit quality without reducing endocarp growth. Scientia Hort. 150:73-79.

Zhang, C. and M.D. Whiting. 2011. Improving 'Bing' sweet cherry fruit quality with plant growth regulators. Scientia Hort. 127: 341-346.

Zhang, C., N. Tateishi, and K. Tanabe. 2010. Pollen density on the stigma affects endogenous gibberellin metabolism, seed and fruit set, and fruit quality in Pyrus pyrifolia. J. Experimental Bot. 61:4291-4302. 